\title{
Intra and Inter-Neighborhood Income Inequality and Crime
}

\author{
Thomas D. Stucky, Seth B. Paytona \& John R. Ottensmann
}

\begin{abstract}
One important factor in many macro-level theories of crime is income inequality. Although research generally shows that low levels of neighborhood income are associated with crime, research studies have been less clear on whether income inequality is a robust, independent predictor of crime, particularly in small area studies and few studies have explicitly considered income inequality between neighborhoods, and those that do typically focus on homicide. The current study examines whether within and between-neighborhood income inequality is associated with variation in violent and property crime. We employ geocoded Uniform Crime Report data from the Indianapolis police department and economic and demographic characteristics of the population from the American Community Survey for 2005 to 2009. Consistent with prior research, lower levels of income were associated with higher violent and property crime counts. Within-tract income inequality was also associated with higher UCR violent and property crimes in most models. Results also showed that the ratio of tract income levels to neighboring tracts is associated with variation in crime. Thus, both local and nearby income inequality affect crime. Implications for theory and policy are discussed.
\end{abstract}

Keywords: Income inequality, crime, spatial analysis

This is the author's manuscript of the article published in final edited form as:

Stucky, T. D., Payton, S. B., \& Ottensmann, J. R. (2015). Intra-and inter-neighborhood income inequality and crime. Journal of Crime and Justice, (ahead-of-print), 1-18. http://dx.doi.org/10.1080/0735648X.2015.1004551 


\section{Introduction}

The detrimental effects of high levels income inequality have recently become the subject of discussion in national political circles. ${ }^{1}$ Yet, the potentially harmful effects of income inequality have been a longstanding concern for crime researchers. A substantial amount of research has examined whether low levels of income in an area are associated with higher crime. ${ }^{2}$ These studies typically focus on how poverty and unstable housing or families affect intra-community informal social control and ultimately crime (e.g. Morenoff, Sampson, and Raudenbush 2001; Sampson and Groves 1989; Sampson, Raudenbush, and Earls 1997). Others (see Hipp 2007) argue that income inequality can also increase crime, though empirical findings have been mixed (for discussions see Ousey and Lee 2013; Patterson 1991). In addition, many studies of income inequality and crime have been conducted at large levels of aggregation such as nations (Chamlin and Cochran 2006; Nivette 2011; Pratt and Godsey 2003), cities (Harer and Steffensmeier 1992; Kovandzic, Vieraitis, and Yeisley 1998; Parker and McCall 1997; Shihadeh and Steffensmeier 1994) or SMSAs (Blau and Blau 1982) (see Ousey and Lee 2013 for an overview). Several studies (e.g. Crutchfield 1989; Hipp 2007; Mears and Bhati 2006; Messner and Tardiff 1986; Patterson 1991; Wang and Arnold 2008), have considered these issues at lower levels of analysis such as neighborhood clusters or census tracts. As elaborated further below, theory and some research evidence suggest that income levels and inequality within neighborhoods affect crime. Boggess and Hipp (2014:7) note that recent research focuses on how the economic conditions of nearby areas may matter for neighborhood crime. Thus, it is

\footnotetext{
1 The New York Times even has a section of its website devoted to the issues surrounding income inequality. http://topics.nytimes.com/top/reference/timestopics/subjects/i/income/income_inequality/index.html.

2 For recent research focusing on the effects of the related but broader concept "disadvantage” on crime see Hipp 2010; Hipp and Yates 2011; Krivo, Peterson, and Kuhl 2009; Peterson and Krivo 2009; Stretesky, Shuck, and Hogan 2004.
} 
important to also consider between neighborhood income inequality. To date, most studies that have explicitly modeled within and between neighborhood income inequality have focused on homicide and used data from the city of Chicago (e.g. Mears and Bhati, 2006; Morenoff et al, 2001). In this study, we explore whether and how within and between neighborhood income inequality affect several types of serious crime, controlling for low levels of income. To do this, we employ geocoded UCR crime data from 2007-2009 from the Indianapolis Metropolitan Police Department (IMPD) combined with income and socio-demographic characteristics of census tracts from the American Community Survey from 2005-2009.

\section{Income Inequality and Crime}

There are several theoretical reasons why income inequality and crime may be related (see Hagan and Peterson 1995; Hipp 2007; Ousey and Lee 2013 for discussions). ${ }^{3}$ Indeed, Hipp (2007: 668, Table 1) notes four different potential mechanisms by which general inequality and crime may be related, including social disorganization, relative deprivation, social distance, and routine activities theory. ${ }^{4}$ For example, social disorganization theory focuses on the ability to maintain informal social control within a neighborhood. Income inequality may reduce the capacity for community informal social control by adversely affecting family stability, social networks, supervision of youth and what Sampson, Raudenbush, and Earls (1997) refer to as "collective efficacy". Income inequality may also increase social distance between the rich and the poor, reducing the likelihood of social interaction necessary for maintaining informal social control and lead to social and cultural isolation that can create criminogenic cultural

\footnotetext{
${ }^{3}$ Although we focus here on inequality, research generally shows that low levels of income (poverty) and crime are related, though this finding is not universal (see Ousey and Lee 2013; Patterson 1991).

${ }^{4}$ Hipp (2007) adds two additional mechanisms when discussing inter-racial inequality or ethnic heterogeneity, namely consolidated inequality and group threat.
} 
adaptations. ${ }^{5}$ Income inequality may also induce feelings of "relative deprivation" for those with fewer resources. ${ }^{6}$ From this perspective, crime would likely result from resentment or anger on the part of the "have nots" against the "haves". Finally, routine activities theory suggests that crime occurs when motivated offenders encounter suitable targets in the absence of capable guardians. Inequality could lead to crime by increasing the pressure for the poor to obtain goods and thereby increasing the number of motivated offenders. It could also lead to increased crime by reducing guardianship because those with few resources might be less able to take appropriate security measures. Finally, it may be that inequality increases crime by placing those with few resources near those with greater resources (and therefore goods or people that can be considered suitable targets). Therefore, there are good theoretical reasons to believe that income inequality is related to crime.

Studies with large units of analysis generally show a link between inequality and crime. Pratt and Godsey (2003), for example, found that income inequality predicted cross-national variation in homicide rates in 46 countries. There have also been several studies at lower levels of aggregation such as cities (Harer and Steffensmeier 1992; Kovandzic, Vieraitis, and Yeisley 1998; Parker and McCall 1997; Shihadeh and Steffensmeier 1994) or SMSAs (Blau and Blau 1982). For example, Kovandzic, Vieraitis, and Yeisley (1998) found that three separate measures of income inequality and income levels (poverty and unemployment) have independent effects on homicide in a study of 190 large cities in $1990 .^{7}$

\footnotetext{
${ }^{5}$ For an excellent discussion of modern thinking on culture and crime see Sampson and Bean 2006.

${ }^{6}$ Blau and Blau (1982) argue that inter-racial income inequality may engender anger and resentment and we agree. However, there is no reason to believe that intra-racial income inequality could not also produce a feeling of relative deprivation. We appreciate the suggestion of an anonymous reviewer that this point be clarified.

${ }^{7}$ Also at the city-level, Velez, Krivo, and Peterson (2003) examined the effects of black-white gaps in poverty, female headed families, male unemployment, income, percentages of college graduates on the racial gap in homicide offending in 126 central cities in 1990. They found that higher homicide rates for blacks are due to lower rates of income, college graduates and professionals in the work force among Blacks (see also Ulmer, Harris, and Steffensmeier 2012).
} 
Studies have also examined the effects of income inequality on crime with smaller units of analysis. For two early studies see Messner and Tardiff (1986) who studied 26 identified neighborhoods (somewhat larger than census tracts) in Manhattan, NY and Crutchfield (1989) who studied the effect of poverty and income inequality in Seattle census tracts. Hipp (2007) focused on income inequality in his study of crime in census tracts in 19 cities in 2000. Controlling for several other factors, he finds that overall and within-race income inequality in a tract are significant predictors of homicide, aggravated assault, and robbery but not burglary or theft. Finally, though the main focus of the study was on examining whether there are non-linear effects of poverty on crime, Hipp and Yates (2011) found that inequality was a significant predictor of violent and property crime (see Table 2, p.980) in census tracts in 25 cities. Thus, several recent studies suggest that income inequality within a neighborhood affects crime. ${ }^{8}$

\section{Local and Nearby Income Inequality}

As noted above, Hipp (2007) specifies four theories that relate overall income inequality and crime, each operating at potentially distinct geographic levels. Social disorganization and social distance theories are posited to operate primarily within a neighborhood. Routine activities theory is posited to operate "nearby". Thus, routine activities theory would suggest that crime would be higher when those with few resources live in proximity to those with items that can be stolen, as these situations provide more opportunities for motivated offenders and suitable crime targets to come into contact (Hipp 2007). The "travel to crime" literature suggests that offenders generally stick close to home so "nearby" is more likely to be one’s neighborhood

\footnotetext{
${ }^{8}$ Studies at the city level also suggest that poverty and inequality clustering are associated with crime. Stretesky, Shuck, and Hogan (2004) examined the link between the geographic clustering of poverty and violent crime. They found that an index of disadvantage (percent poor, percent female headed households, percent black, percent unemployed) had a stronger effect on homicide in cities with high levels of poverty concentration. Similarly, Hipp (2011) examined 352 cities from 1970 to 2000 that experienced rapid growth and found (p.649) that "[c]ities with very high levels of inequality and economic segregation — walled-off fortresses of wealth-will have the highest assault rates...”
} 
or those in close proximity (see e.g. Bernsaco, 2010; Townsley \&Sidebottom, 2010) than across town. According to Hipp (2007), relative deprivation theory does not articulate a specific geographic level at which it operates. We argue, however, that the conditions in one's neighborhood and those nearby are more likely to be relevant comparison points for the theory than the city as a whole or areas across town. One’s own and immediately surrounding neighborhoods likely serve as important mental reference points, particularly given the geographically finite “awareness spaces” within which most people (including criminals) typically operate (see Brantingham and Brantingham 1984, 1993). So, spatially proximate neighborhoods are those that are most important in determining whether one feels poor in comparison to others (for a similar argument, see Crutchfield 1989: 497).

Boggess and Hipp (2014:7) note that there has been an increasing focus on the spatial context of neighborhoods and how the characteristics of surrounding areas might matter for crime. In their study, Boggess and Hipp (2014) considered gentrification over time in Los Angeles census tracts. They found that tracts experiencing economic revitalization (gentrification) were more likely to have higher crime if they were near areas that were not experiencing economic development than those neighborhoods that were surrounded by other neighborhoods experiencing revitalization. Consistent with this logic (though unlike Boggess and Hipp (2014) focusing on current conditions rather than change over time), we argue that theory and empirical evidence suggest that economic conditions such as inequality in one’s own area and those that surround it are likely to matter for crime. A few research studies have explicitly considered within and between neighborhood income inequality .

Morenoff, Sampson, and Raudenbush (2001) studied the effects of concentrated disadvantage, inequality, and collective efficacy on homicide in 343 neighborhood clusters in 
Chicago. Net of other factors, including a spatial lag, Morenoff et al. (2001) found that the effects of inequality on homicide were greatest within the neighborhood but extended to areas beyond the neighborhood. Thus, there were fairly substantial effects of concentrated disadvantage in the first order neighbors of the neighborhood and to a much lesser extent the second and third order neighbors. This is a very illuminating study and shows the desirability of considering areas beyond the immediate neighborhood. Similarly, Mears and Bhati (2006) considered the effects of the somewhat broader concept of "resource deprivation" (an index of percent poor, percent female-headed households, percent unemployed, median family income, and median household income) in nearby areas on homicide in 343 Chicago neighborhood clusters (aggregated from census tracts). They found that resource deprivation in nearby areas has a greater effect on homicide in areas that are both spatially proximate and similar in terms of race/ethnic composition. The Mears and Bhati (2006) study suggests that crime is a function of characteristics in nearby areas but does not specifically measure income inequality and focuses only on homicide. Finally, Wang and Arnold (2008) include a measure of "localized income inequality” in their study of homicide for census tracts, neighborhood clusters, and community areas in Chicago. Unfortunately, this measure is included as part of a deprivation index, so it is not possible to determine the independent effect of income inequality in the study. Thus, one question that remains is whether similar effects would be seen with other crimes and in other cities. We believe the theories discussed here are somewhat agnostic on the degree to which inequality would affect violent or property crime, or both. For example, relative deprivation theory might suggest that inequality would produce anger and therefore violent crime (though perhaps not just homicide). However, routine activities theory would suggest that property crimes such as burglary and theft could be increased as well as robbery when inequality leads to 
more motivated offenders meeting suitable targets. Thus, we argue that a study that considers all types of crime is useful.

In sum, there are good reasons to believe that income levels and inequality within neighborhoods affect crime (see Hipp 2007). A few studies have considered how income inequality between neighborhoods might matter for crime but they have focused mainly on homicide (Mears and Bhati 2006; Morenoff et al. 2001; Wang and Arnold, 2008) or have included income inequality as part of a broader “disadvantage” measure (Mears and Bhati, 2006; Wang and Arnold, 2008). The goal of the current study is to focus specifically on income inequality and explore whether and how within and between-neighborhood income inequality affect a variety of serious crimes. In the next section, we discuss the data and methods used in the current study.

\section{DATA AND METHODS}

Crime data for this analysis come from Uniform Crime Reports (UCR) obtained from the Indianapolis Metropolitan Police Department (IMPD). Income and other neighborhood attributes were collected from the U.S. Bureau of the Census, American Community Survey (2005-2009). The unit of analysis is the census tract, and we employ tracts as specified in the 2000 census. The study area includes all areas in Marion County in which police services were consolidated in 2008. ${ }^{9}$ Four municipalities were excluded from the IMPD consolidation. Tracts with over 10 percent land area within excluded municipalities were not included in the analysis. Excluding those tracts reduced the number of observations from 212 to 188.

\footnotetext{
${ }^{9}$ Prior to 2008, the Indianapolis Police Department service area was essentially congruent with City of Indianapolis boundaries before the city and county consolidated most other public service in 1970. In 2008, the Indianapolis Police Department merged with the Marion County Sheriff's Department to form the Indianapolis Metropolitan Police Department. That merger expanded the service area controlled by the City of Indianapolis to nearly all of Marion County, with exception of municipalities that have remained excluded from major municipal services in Marion County. Those excluded areas include: Beech Grove, Lawrence, Southport, and Speedway.
} 


\section{Dependent Variables}

UCR crime counts in the study area, by census tract, from 2007 through 2009 are utilized as outcomes. Aggregating three years of reported crimes minimizes the potential error associated with random year-to-year variation. This analysis considers aggregate counts of UCR property

and violent crimes within the census tracts. Individual crime types are also examined separately (i.e., criminal homicides, rapes, robberies, aggravated assaults, burglaries, larcenies, and vehicle thefts).

Income Variables

The present study examines income levels and inequality within and between tracts, specifically: tract mean income, within tract inequality, as measured by the Gini coefficient, and between tract income inequality, as indicated by the ratio of adjacent to tract mean income. Because there are several measures that could potentially be used to predict the effects of each aspect on crime and prior research has produced mixed findings on the effects of income inequality on crime, we extensively examined several indicators of income levels and inequality to ensure that conclusions drawn are not dependent upon the operationalization of income. For more information on the strategy we used to determine which income variables to include in the models reported here and additional results see Appendix 1.

Level of tract income is measured by the mean household income. Household income was chosen because it is the most inclusive income measure and is most consistent with the primary focus of measuring income inequality by the U.S. Census Bureau (e.g., Persky and Tam 
1990; Weinberg 2011). We chose mean, rather than the median, because it exploits the entire income distribution. ${ }^{10}$

The Gini coefficient is the most commonly used measure of income inequality (see Jones and Weinberg 2000; Kim and Jargowsky 2005). Therefore, to capture within tract income inequality, we employ the Gini coefficient, which is based on the frequency of households at different levels of income. That measure ranges from zero to one. Zero represents perfect equality and one indicates maximum inequality within each tract. ${ }^{11}$ Between tract income inequality is measured by dividing adjacent tract mean household income by tract mean household income. Using this ratio as a measure of income inequality between groups or neighborhoods has been suggested by several scholars (e.g., Fossett and South 1983; Wang and Arnold 2008) ${ }^{12}$. Using the ratio as a measure of intergroup income inequality preserves important qualities about direction of the intergroup inequality and the magnitude of difference between two groups.

\section{Control Variables}

\footnotetext{
${ }^{10}$ Fossett and South (1983) provide a compelling argument about the choice of using mean income instead of median income when comparing group differences. They acknowledge that the median is justified when there is reason to believe that extreme values are "misrepresented.” Their argument reasonably suggests that if there is no reason to believe that there is a misrepresentation of extreme values, then the entire distribution (e.g., lower income, middle income, and higher income) should be considered when attempting to represent the level of income of a group. We contend that the ACS Census tract level data, sampled over a five year period, mitigates much of the expected misrepresented error associated with extreme values. Therefore, including the entire distribution in the estimate of income level is reasonable. While focus on the level of income through the mean is consistent with that reasoning, we performed multiple sensitivity analyses that indicate that conclusions are relatively unaltered when considering median-based measures.

11 The Pareto-linear estimation method was use to estimate the within income interval means necessary to calculate the Gini coefficient (see Miller 1966, pp. 215-216). This method has been used by the Census (1987) and several scholars (Cloutier 1988, 1997; Hipp 2007, 2011; Jargowsky 1995, 1996; Lee 2005; Neilsen and Alderson 1997; Persky and Tam 1990; Watson 2009). The Pareto-linear method assumes a linear distribution in lower income intervals and a Pareto distribution in upper income categories. The upper income intervals include the interval containing the median and those above.

${ }^{12}$ Similar to the justification of the tract mean level of income, the logic of Fossett and South (1983) suggests that the ratio of means is the most reasonable measure of intergroup comparisons. Again, sensitivity analyses indicate that median-based measures of inter-neighborhood income inequality do not affect our overall conclusions.
} 
To determine the other variables to include in our analyses, we conducted a survey of several other studies of income inequality (Hipp 2007, 2010, 2011; Hipp and Yates 2011; Kovandzic et al 1998; Mears and Bhati 2006; Morenoff et al 2001). Although space considerations preclude an extended discussion of this analysis, we concluded that most studies include some indicator of the broad set of empirical indicators we include in our analyses. The specific indicators of these concepts, however, were measured in a variety of ways. So we chose the empirical indicators that we felt best captured the important macro-level factors associated with crime in census tracts.

\section{$\underline{\text { Disadvantage Index }}$}

Following previous research, a disadvantage index is included in the models (Land, McCall and Cohen 1990; Parker and McCall 1999). Indicators in that index include: percentage of female headed households and percentage of persons in the labor force who are unemployed. Principal Components Analysis was used to reduce those indicators into one index. The Factor loading on this index is 0.88 and the variation accounted for by the first component is 0.77 . It should be noted that income is often included in disadvantage indices. Since we are interested in the independent effect of income, it is not included in the disadvantage index for this analysis.

\section{$\underline{\text { Stability Index }}$}

Previous research also finds a relationship between crime and neighborhood instability (e.g., Wilcox et al. 2004). Using principal components analysis, a stability index was created that included the percentage of owner-occupied housing units and the percentage of the population that had not moved within five years. The absolute value of the factor loading for this index is 0.92 and the proportion of the variation accounted for by the first component is 0.83 . 


\section{Adapted Herfindahl Index}

Social disorganization theory also focuses on the detrimental effects of ethnic heterogeneity. Therefore, Hipp’s (2011) adapted Herfindahl index is used to measure the extent of variation in racial and ethnic makeup of tract population. ${ }^{13}$ That index takes the minimum value when all members of the population are the same race or ethnicity, while the maximum value indicates that there is an even distribution across all groups. The formula for the index is:

$$
H=1-\sum_{i-1}^{n} p_{i}^{2}
$$

where $\mathrm{p}_{\mathrm{i}}$ is the proportion of the population in each of $\mathrm{n}$ racial and ethnic groups. ${ }^{14}$ The index includes four groups: Not Hispanic or Latino, White alone; Not Hispanic or Latino, Black or African-American alone; Hispanic or Latino; Not Hispanic or Latino, all other races. ${ }^{15}$

\section{$\underline{\text { Other Control Variables }}$}

The percentage of Hispanic population, African American population, and percentage of population aged 15-24 within each census tract are included as additional control variables, based on a survey of several prior studies in this area (e.g. Hipp 2007, 2010, 2011; Hipp and Yates 2011; Kovandzic et al 1998; Mears and Bhati 2006; Morenoff et al 2001). Table 1 shows basic descriptive statistics for variables used in the analyses.

Prior studies have shown that socio-economic factors such as those included in the current study are often highly correlated. In addition to the multiple sensitivity analyses

\footnotetext{
13 The original Herfindahl (or Herfindahl-Hirschmann) index was a measure of homogeneity. Specifically, the index was created to measure market concentration.

${ }^{14}$ Note that the adaptation is that the original index is subtracted from one, making it a measure of heterogeneity rather than a measure of homogeneity.

${ }^{15}$ Unlike Hipp (2011), we do not include Asians as a separate group because of the small Asian population in Indianapolis.
} 
associated with the specification of income inequality measures reported in the Appendix, we examined the influence of potential multicollinearity. Because it is not possible to directly test for multicollinearity in negative binomial models, we estimated a series ordinary least square (OLS) models that are analogous to the negative binomial modes presented in Tables 2 and 3. Understanding that such models are not perfect substitutes for preferred count models, we are able to provide some evidence that multicollinearity is likely not driving our results. Variance inflation factors produced from our OLS models were thoroughly examined and generally do not indicate any issues related to the multicollinearity of independent variables. VIFs values in these models averaged 2.03 and only one variable had a VIF higher than 3 (the disadvantage index had a value of 3.37 with all control variables included).

\section{Table 1 about here}

\section{Modeling Strategy}

Theory and empirical evidence suggest that crime is a function of neighborhood stability (e.g., extent to which the neighborhood experiences high levels of resident mobility), levels of disadvantage (i.e., extent to which residents are disadvantaged) and demographic characteristics of neighborhoods (e.g., racial composition and age of population). In this paper, we focus primarily on the impact of income inequality within and between neighborhoods, measured in a variety of ways.

The count of crimes in each census tract serves as the dependent variable. Crime counts are distributed such that large numbers of tracts have few crimes whereas a small number of tracts have higher numbers of reported crimes. Therefore, the normality assumption necessary for linear regression is violated. Count data (e.g., crime events in a census tract) more closely follow a Poisson or negative binomial distribution (Greene 2000; Osgood 2000; Osgood and 
Chambers 2000). Poisson regression assumes that the mean of the outcome is equal to its variance. If that assumption is violated, then Poisson regression is not an appropriate method due to over-dispersion and the more appropriate model is negative binomial regression because a dispersion parameter is included in the model. For those reasons, negative binomial regression is used to estimate the results reported below. The models reported below also include population as an exposure variable and a spatial lag crime variable (i.e., the average count of crime in spatially contiguous tracts). The exposure variable is included to address the expected increase in potential for crime as population in a tract increases. The spatial lag variable is included to mitigate expected spatial autocorrelation. The Moran's I statistic, calculated for violent crimes and property crimes, is consistent with that expectation. The global Moran's I statistic for violent crimes was 0.415 and was 0.157 for property crimes. Both of those values were statistically significantly different from zero at $p<0.001$. As a measure including income in the surrounding tracts is already included in the model, the addition of the spatial lag of crime could be introducing a degree of endogeneity into the models. Given the high levels of spatial autocorrelation for many of the models and the significance of the spatial lag variable in many of the models, we chose to include the spatial lag in the models reported. Models without the spatial lag produce similar results, with virtually no differences in patterns of significance. The z-scores for the income variables in the models with the spatial lag are lower than those in the models without (in 24 out of 27 cases). Therefore, reporting the results for the models with the spatial lag is the more conservative alternative.

\section{RESULTS}

The purpose of this paper is to examine the effect of within and between tract income inequality on violent and property crimes. Table 2 shows the results of negative binomial models 
predicting aggregated and individual UCR violent crime counts (homicide, rape, robbery, and aggravated assault). Consistent with most prior studies, the level of tract income is statistically negatively associated with aggregate UCR violent crime counts, as well as counts of specific UCR violent crimes by type in all models in Table 2. Thus, fewer violent crimes are expected in higher income neighborhoods. In addition, within tract income inequality, as measured by the Gini coefficient is a statistically significant $(p<0.05)$ predictor of aggregated and individual UCR violent crime counts (except homicide). The number of violent crimes is also significantly associated with between tract income inequality (i.e., ratio of adjacent tract mean income to tract mean income) for aggregated UCR violent crime counts. Thus, violent crimes are generally higher when the surrounding tracts have lower incomes. The significance of that relationship with aggregated violent crime may be particularly driven by rapes and aggravated assaults, as there seemingly is not a significant relationship between nearby neighborhood income and homicides or robberies.

Table 2 about here

Table 3 shows the results of identical models to predict aggregated and individual UCR property crimes (burglary, larceny, motor vehicle theft). In all models of table 3, property crime is statistically significantly lower when within-tract income levels are higher. Property crimes (aggregated and individual) are also statistically significantly higher when income inequality (i.e. the Gini coefficient) within a tract is higher. In addition, aggregated and individual UCR property crime counts are higher when between tract income inequality is higher, particularly when the income levels of adjacent tracts are lower compared to the tract income (as indicated by the ratio of adjacent to tract mean income). Thus, the effects of income levels and inequality within a tract and the ratio of income in adjacent tracts matter for property crime. 
Table 3 about here

The results of the models presented here are generally consistent across different measures for income inequality and crime type. Mean tract income levels are statistically significantly negatively associated with aggregated and individual UCR violent and property crime counts in all models in Tables 2 and 3. Within tract income inequality (Gini coefficient) is significantly related to higher counts of aggregated and individual UCR violent and property crime counts except homicide. Interestingly, between tract income inequality was a significant predictor of aggregated and individual violent and property crime counts except homicide and robbery.

To illustrate the magnitude of each key variable, Table 4 shows predicted marginal effect of increasing each of the key variables by one standard deviation on the three year count of specific types of crime. The predicted marginal change of those variables was calculated separately while holding all other variables at the mean. For instance, a one standard deviation increase in tract mean income (i.e., $\$ 55,874$ to $\$ 83,686$ ), while holding all other neighborhood characteristics at the mean, is predicted to decrease the average number of homicides $(\mu=1.5)$ by 0.13. Under the same conditions, a one standard deviation increase in mean income is predicted to result in 3.0 fewer rapes ( $\mu=6.7)$, 22.3 fewer robberies $(\mu=57.2)$, and 34 fewer aggravated assaults. $(\mu=75.2)$. Within-tract income inequality (the Gini coefficient) was a statistically significant predictor of rape, robbery, and aggravated assault, but not homicide. Increasing within tract inequality (i.e., the tract income Gini coefficient) by one standard deviation from the mean is estimated to increase the number of rapes by 1.6, robberies are predicted increase by 18.6, and aggravated assaults are expected to increase by 9.5. Finally, between-tract income inequality also is not a statistically significant predictor of homicide, but is statistically 
significant for the other three individual types of violent crimes. Specifically, all types of violent crime are higher when tract income is higher relative to the mean income of adjacent tracts. When the mean of that ratio (1.13) is increased by one standard deviation (0.33), the estimated result is 0.8 fewer rapes, 5.8 fewer robberies, and 13.7 fewer aggravated assaults.

\section{Table 4 about here}

The key inequality variables were significantly related to change in each of the specific types of property crime. Based on our models, a one standard deviation increase in tract level income is predicted to result in 63 fewer burglaries, approximately 105 fewer larcenies, and 42 fewer vehicle thefts. In terms of within tract inequality, increasing the tract income Gini coefficient by one standard deviation is predicted to result in a 13.85 increase in burglaries, 41 more larcenies, and 10 more vehicle thefts. Finally, with respect to between tract inequality, a one standard deviation increase in the adjacent tract ratio is estimated to decrease burglaries by 14, result in 38 fewer larcenies, and 14 fewer vehicle thefts.

Next, we briefly discuss the effects of control variables on tract violent and property crime counts. The most consistent control variable is the measure of residential stability, which is statistically significantly negatively associated with the aggregated UCR violent crime counts and all individual UCR violent crimes, except homicide. Somewhat surprisingly, the disadvantage index is not a consistent predictor of any UCR violent crime in Table 2, net of the other variables in the model. Although this might seem counterintuitive, given the consistent significance of this variable in other studies, most other studies include income variables in disadvantage indices (e.g. Parker and McCall 1999). Although this is not the main focus of the study, this finding deserves additional research in the future. It may be that these income variables are the most important drivers of the effects of the disadvantage index on crime in 
macro-level studies. In terms of race and ethnicity, the percent of tract residents who are African American is a statistically significant predictor of aggregated UCR violent crime counts, homicides and aggravated assaults but not rapes or robberies. Interestingly, the percent of residents who are Hispanic and the Herfindal heterogeneity index are not statistically significant predictors of aggregated or individual types of UCR violent crime counts in Table 2. Three of five models indicate that a higher percentage of males aged 15-24 is associated with significantly lower crime, which is unexpected. And, consistent with the significance of the Moran’s I statistic for spatial autocorrelation, aggregated violent crime counts, robberies, and aggravated assaults (though not homicides or rapes) are higher in tracts where the surrounding tract counts of those crimes are higher (spatial lag variable).

The results for property crime generally mirror those of the violent crime models. For example, racial heterogeneity and the percent of tract residents who are Hispanic are not statistically significant predictors of UCR property crime counts in any model in Table 3 and percentage African American in a tract is only a statistically significant predictor of burglary counts. Tract residential stability is also a significant predictor of aggregated UCR property crime counts and larcenies and vehicle thefts (but not burglaries). And similar to the violent crime models, the disadvantage index is not a significant predictor of tract property crime counts, net of the other variables in the model. Percent of males age 15-24 in a tract is statistically significantly negatively associated with burglaries and vehicle thefts (again surprisingly). The spatial lag variable is significant for burglaries, and vehicle thefts but not aggregated property crimes or larcenies.

Because the results of the effects of income inequality on crime in prior studies have been mixed, we estimated models that captured income levels and inequality, both within and across 
tracts. Although the models presented in Tables 2 and 3 produce fairly consistent results of the effect of income variables, controlling for a variety of other factors, the results presented here could be dependent on model specification. To test the robustness of these results to model specification, similar models were estimated using ordinary least squares (number of crimes plus one as the dependent variable), negative binomial regression without an exposure variable, and negative binomial regression with area of tract as the exposure variable. We also examined multiple measures of tract income level, intra-tract income inequality, and inter-tract inequality (see Appendix for discussion). The general substantive conclusions one would draw regarding the effects of within and across tract income levels and inequality on crime are consistent, regardless of model specification.

\section{DISCUSSION AND CONCLUSIONS}

There has been a longstanding focus on the effects of income inequality on crime, with mixed results (see Ousey and Lee 2013). Recent research focuses on how aspects of the neighborhood and surrounding areas matter for crime (e.g. Boggess and Hipp 2014). We noted that there are good theoretical and empirical reasons to consider income inequality within and between neighborhoods. Indeed, several prior studies have considered how inequality in nearby areas affects homicide in Chicago (Mears and Bhati, 2006; Morenoff et al. 2001; Wang and Arnold 2008). ${ }^{16}$ Extant theory does not appear to suggest that the impact of inequality would be limited to homicide, therefore, we examined the effects of within and between neighborhood income inequality on several measures of a variety of serious violent and property crimes, using crime data for census tracts from 2007 to 2009 in Indianapolis. We controlled for low income levels within tracts and perhaps not surprisingly, net of other factors, low income tracts had more

\footnotetext{
${ }^{16} \mathrm{Hipp}$ (2007) also explores these issues using a two stage least squares approach. Thus, no empirical estimate of between tract income inequality is reported in the study.
} 
crime. We also found fairly consistent evidence that, net of income levels and other factors, higher within-tract income inequality was associated with higher violent and property crime counts. These findings are generally consistent with similar prior studies of income inequality and crime (e.g. Hipp 2007, Mears \& Bhati 2006; Morenoff et al 2001). Somewhat surprisingly, however, we did not find strong effects of inequality on homicide in the current study, whereas those studies focused exclusively on homicide.

Because theory suggested that the relative income of the tract and those surrounding it might affect crime, we also investigated whether between-tract income inequality was related to crime. We found evidence across a variety of model specifications and most types of crimes that it was. Specifically, between tract income inequality (i.e. the ratio of mean income to adjacent tract income) predicted crime, net of other factors. The coefficient was negative, which means that tract crime is lower when neighboring tracts have higher income. Interestingly, we did not find that homicide and robberies were predicted by this ratio. This was somewhat surprising given that several other studies had found an effect of inequality in surrounding areas on homicide (Mears and Bhati, 2006 and Morenoff et al 2001).

The findings of the current study add to a growing body of research that shows the importance of the characteristics of surrounding neighborhoods for crime. As we noted above, Boggess and Hipp (2014) found that gentrification in nearby areas affects crime in the neighborhood. Though our study was cross-sectional, it also suggests that the economic conditions of nearby areas affect crime. These findings deserve additional research in the future and could have implications for theory. For example, social disorganization theory has been critiqued in the past for treating neighborhoods as freestanding independent entities. The findings of the current study add weight to the idea that both the area and its surroundings matter 
for crime. Therefore, it would seem that one logical next step for examining social disorganization theory is to consider the embeddedness of the neighborhood in its surroundings. One intriguing avenue for such efforts comes from a recent paper by Hipp and Boessen (2013) who described a city in terms of "egohoods". So rather than having discrete boundaries, neighborhoods extend in waves outward from the focal location. Though it was beyond the scope of the current paper to incorporate the specific empirical technique, we applaud Hipp and Boessen's work in attempting to push past the traditional boundary driven approach to thinking about units of analysis and "neighborhood”. Of course, Hipp and Boessen’s (2013) study also showed the importance of income inequality for predicting crime. Indeed, we argue that our approach for capturing inequality across neighborhoods is consistent with the logic Hipp and Boessen (2013: 315) describe, "one might wish to construct a measure of the difference in the income level of the surrounding buffer and in the income level of the block as one way to capture inequality in the ISE approach.” Though we employed census tracts, we compared income in the tract to income in the surrounding tracts as a measure of inequality.

These findings add to the research literature by providing additional evidence that income inequality affect a variety of property and violent crimes, and that both within and between neighborhood income inequality matter for crime. Although not the main focus of this study, we also found that race and ethnicity variables were not consistently associated with tract crime, in multivariate models controlling for income levels and inequality. Indeed, ethnic heterogeneity and the percent Hispanic were unrelated to any crime and percent African American predicted primarily violent crimes. Similarly, other elements of disadvantage (unemployment and female headed households) were not consistent predictors of crime with income included as a separate measure. This pattern of results suggests that income may be the most critical element of socio- 
economic disadvantage to consider for crime, but this finding should be explored more fully using other data in the future. A measure of residential stability was a fairly robust predictor of violent and property crimes (except homicide and burglary) in the models estimated here, net of controls.

This study is not without its limitations. First, it should be noted that the current study relies on reported crime (which has widely-recognized limitations), and focuses on a single city. The city of Indianapolis is fairly typical of Midwest large cities and we believe it is a generally appropriate place to conduct research on the relationship between income inequality and crime. However, generalizing these findings beyond cities of similar size should be done with caution. The study also focuses on overall inequality rather than within and between race inequality Another avenue for future research is to consider whether the effects of between neighborhood income inequality vary by race and ethnic composition of the neighborhood and surrounding areas. Prior research (e.g. Harer and Steffensmeier 1992; Hipp 2007; Shihadeh and Steffensmeier 1994) suggests that this is quite likely, so an obvious next step is to examine the effects of inter-racial income inequality within and across census tracts.

In sum, we find that within and between-tract income inequality are fairly robust predictors of several types of serious crime, net of other factors including poverty. These results have some important policy implications. First, both local income levels and inequality matter. So policies should focus on ways to reduce both poverty and inequality, though as we noted at the outset, there is currently much discussion of inequality in national-level policy circles and real progress is likely to be difficult and slow. Second, local and nearby economic conditions matter for crime. So city planners should consider how development or revitalization efforts are likely to affect the relative mix of incomes in neighborhoods across the city. The effects of any 
policies are likely to extend beyond the area where money is being spent. Most neighborhood revitalization programs are place-based and require decisions on where limited resources should be invested. Combined with the work of others (e.g. Boggess and Hipp 2014), our research adds to the evidence that specific neighborhood investments (e.g., Neighborhood Stabilization Program, Homeownership Zone, Empowerment Zone) should be considered in light of economic conditions in surrounding neighborhoods. For example, the City of Indianapolis recently followed the strategy of focusing on both distressed neighborhoods and neighborhoods surrounding distressed neighborhoods targeting areas of the city to invest Neighborhood Stabilization Program funds (Author 2009). This study adds to the growing evidence that, in the words of Mears and Bhati (2006), "no community is an island." 


\section{References}

Author. 2009. Recommendations from the Indianapolis Neighborhood Planning Council to Mayor Ballard. Center for Urban Policy and the Environment. Indianapolis, Indiana.

Blau, J R., and Blau, P. M. 1982. The cost of inequality: Metropolitan structure and violent crime. American Sociological Review 47, 114-29.

Bernasco, W. 2010. A sentimental journey to crime: Effects of residential history on crime location choice. Criminology, 48(2), 389-416.

Boggess, L.N. and Hipp, J.R. 2014. The spatial dimensions of gentrification and the consequences for neighborhood crime. Justice Quarterly 1-30

DOI: 10.1080/07418825.2014943799.

Brantingham, P. J., and Brantingham, P. L. 1984.Patterns in crime. New York: MacMillan.

Brantingham, P. L., and Brantingham, P. J. 1993. Nodes, paths and edges: Considerations on the complexity of crime and the physical environment. Journal of Environmental Psychology 13, 328.

Chamlin, M. B., and Cochran, J.K. 2006. Economic inequality, legitimacy, and cross-national homicide rates. Homicide Studies 10, 231-252.

Cloutier, N. R. 1988. Pareto extrapolation using grouped income data. Journal of Regional Science 28, 415-419.

Cloutier, N. R. 1997. Metropolitan income inequality during the 1980s: The impact of urban development, industrial mix, and family structure. Journal of Regional Science 37, 459-478.

Crutchfield, R. D. 1989. Labor stratification and violent crime. Social Forces 68, 489-512.

Fosset, M., and South, S.J. 1983. The measurement of income and race/ethnicity across households and neighborhoods on city crime trajectories. Criminology 49, 631-665.

Greene, W. H.2000. Econometric Analysis, (4th ed.). Upper Saddle River, NJ: Prentice Hall.

Hagan, J., and Peterson, R.D (eds.). 1995. Crime and inequality. Stanford CA: Stanford University Press.

Harer, M. D., and Steffensmeier, D. 1992. The differing effects of economic inequality on black and white rates of violence. Social Forces 70, 1035-1054.

Hipp, J. R. 2007. Income inequality, race, and place: Does the distribution of race and class within neighborhoods affect crime rates? Criminology 45, 665-697. 
Hipp, J. R. 2010. A dynamic view of neighborhoods: The reciprocal relationship between crime and neighborhood structural characteristics. Social Problems 57, 205-230.

Hipp, J. R. 2011. Spreading the wealth: The effect of the distribution of income and race/ethnicity across households and neighborhoods on city crime trajectories. Criminology 49, 631-665.

Hipp, J.R. and Boessen, A. 2013. Egohoods as wave washing across the city: A new measure of “neighborhoods". Criminology, 51, 287-327.

Hipp, J.R., and Yates, D.K. 2011. Ghettos, thresholds, and crime: Does concentrated poverty really have an accelerating increasing effect on crime? Criminology 49, 955-990.

Jargowsky, P. A. 1995. Take the money and run: Economic segregation in U.S. metropolitan areas. Institute for Research on Poverty Discussion Paper n. 1056-95, January. Downloaded from http://www.irp.wisc.edu/publications/dps/pdfs/dp105695.pdf on February 16, 2013.

Jargowsky, P. A. 1996. Take the money and run: Economic segregation in U.S. metropolitan areas. American Sociological Review 61, 984-998.

Jones, A. F., Jr., and Weinberg, D.H. 2000. The changing shape of the nation's income distribution: 1947-1998. U.S. Census Bureau Current Population Reports. P. 50-204. June. Downloaded from http://www2.census.gov/prod2/popscan/p60-204.pdf February 182013.

Kim, J., and Jargowsky, P. A. 2005. The Gini coefficient and segregation on a continuous variable. National Poverty Center Working Paper Series \#05-2.Downloaded from http://nationalpovertycenter.com/publications /workingpaper05/paper02/Kim_Jarowsky_Gini_Segregation.pdf on February 272013.

Kovandzic, T. V., Vieraitis, L. M., and Yeisley, M.R. 1998.The structural covariates of urban homicide: Reassessing the impact of income inequality and poverty in the post-Reagan Era. Criminology36, 569-600.

Krivo, L. J., Peterson, R.D., and Kuhl, D.C. 2009. Segregation, racial structure, and neighborhood violent crime. American Journal of Sociology 114, 1765-1802.

Land, K. C., McCall, P. L., and Cohen, L.E. 1990. Structural covariates of homicide rates: Are there any invariances across time and social space? American Journal of Sociology 95, 922-963.

Lee, S. K. 2005. Economic and environmental equity in the U.S. nonmetropolitan tourism and recreation dependent communities. Ph.D. dissertation, Texas A\&M University.

Logan, J. R., and Messner, S.F. 1987. Racial residential segregation and suburban violent crime. Social Science Quarterly 68, 510-527. 
Mears, D. P., and Bhati, A.S. 2006. No community is an island: The effects of resource deprivation on urban violence in spatially and socially proximate communities. Criminology 44, 509-548.

Messner, S. F., and Tardiff, K. 1986. Economic inequality and levels of homicide: An analysis of urban neighborhoods. Criminology 24, 297-316.

Miller, H. P. 1966. Income distribution in the United States. U.S. Census Bureau. A 1960 Census Monograph. Washington, DC: U.S. Government Printing Office.

Morenoff, J. D., Sampson, R.J., and Raudenbush, S. W. 2001. Neighborhood inequality, collective efficacy, and the spatial dynamics of urban violence. Criminology 39, 517-559.

Nielsen, F., and Alderson, A. S. 1997. The Kuznets curve and the great U-turn: Income inequality in U.S. counties 1970 to 1990. American Sociological Review 62, 12-33.

Nivette, A. E. 2011. Cross-national predictors of crime: A meta-analysis. Homicide Studies 15, 103-131.

Osgood, D. W. 2000. Poisson-based regression analysis of aggregate crime rates. Journal of Quantitative Criminology 16, 21-43.

Osgood, D. W., and Chambers, J.M. 2000. Social disorganization outside the metropolis: An Analysis of rural youth violence. Criminology 38, 81-116.

Ousey, G. C., and Lee, M.R. 2013. Community, inequality, and crime, pp. 352-369 in The Oxford handbook of criminological theory. Francis T. Cullen and Pamela Wilcox, eds. New York: Oxford University Press

Parker, K. F., and McCall, P.L. 1997. Adding another piece to the homicide-inequality puzzle: The impact of structural inequality on racially disaggregated homicide rates. Homicide Studies 1, 35-60.

Parker, K. F., and McCall, P.L. 1999. Structural conditions and racial homicide patterns: A look at the multiple disadvantages in urban areas. Criminology 37, 447-477.

Patterson, E.B. 1991. Poverty, income inequality, and community crime rates. Criminology 29, 755-776.

Persky, J., and Tam, M. 1990. Local status and national social welfare. Journal of Regional Science 30, 229-238.

Peterson, R. D., and Krivo, L. J. 1993. Racial segregation and homicide. Social Forces 71, 100126. 
Peterson, R. D., and Krivo, L. J. 2009. Segregated spatial locations, race-ethnic composition, and neighborhood violent crime. The Annals of the American Academy of Political and Social Science 623, 93-107.

Pratt, T. C. and Godsey, T. W. 2003. Social support, inequality, and homicide: A cross-national test of an integrated theoretical model. Criminology 41, 611-644.

Roman, J. 2013. How economic segregation spreads crime like a virus. The Atlantic Cities website. Downloaded from http://www.theatlanticcities.com/politics/2013/01/how-economicsegregation-spreads-crime-virus/4372/ on February 2, 2013.

Sampson, R. J., and Bean, L. 2006. Cultural mechanisms and killing fields: A revised theory of community-level racial inequality. pp. 8-36 in The many colors of crime: Inequalities of race, ethnicity, and crime in America. New York: New York University Press.

Sampson, R.J., and Groves, W. B. 1989. Community structure and crime: Testing socialdisorganization theory. American Journal of Sociology 94, 774-802.

Sampson, R. J., Raudenbush, S., and Earls, F. 1997. Neighborhoods and violent crime: A multilevel study of collective efficacy. Science 277, 918-924.

Shaw, C. R., and Mckay, H. D. 1972. Juvenile delinquency and urban areas, Revised ed. Chicago, Ill: University of Chicago Press.

Shihadeh, E. S., and Flynn, N. 1996. Segregation and crime: The effects of social isolation on the rates of black urban violence. Social Forces 74, 325-52.

Shihadeh, E. S. and Steffensmeier, D. J. 1994. Economic inequality, family disruption, and urban black violence: Cities as units of stratification and social control. Social Forces 73, 729-51.

Stretesky, P. B., Schuck, A. M., and Hogan, M. J. 2004. Space matters: An analysis of poverty, poverty clustering, and violent crime. Justice Quarterly 21, 817-841.

Ulmer, J. T., Harris, C.T., and Steffensmeier, D. 2012. Racial and ethnic disparities in structural disadvantage and crime: White, black, and Hispanic comparisons. Social Science Quarterly 93, 799-819.

U.S. Census Bureau.1987. Money incomes of households, families, and persons in the United States: 1984. Current Population Reports, Series P-60, No. 156. Washington, DC: U.S. Government Printing Office.

Townsley, M., \& Sidebottom, A. 2010. All offenders are equal but some are more equal than others: Variation in journeys to crime between offenders. Criminology, 48(3), 897-918.

Velez, M. B., Krivo, L. J., and Peterson, R.D. 2003. Structural inequality and homicide: An assessment of the black-white gap in killings. Criminology 41, 645-672. 
Wang, F., and Arnold, M. T. 2008. Localized income inequality, concentrated disadvantage and homicide. Applied Geography 28, 259-270.

Watson, T. 2009. Inequality and the measurement of residential segregation by income in American neighborhoods. The Review of Income and Wealth 55, 820-844.

Weinberg, D. H. 2011. U.S. Neighborhood Income Inequality in the 2005-2009 Period. American Community Survey Reports ACS-16. Washington, DC: U.S. Census Bureau.

Wilcox, P., Quisenberry, N., Cabrera, D. T., and Jones, S. 2004. Busy places and broken windows? Toward refining the role of physical structure and process in community crime models. The Sociological Quarterly45, 185-207.

Wilson, W. J.1987. The truly disadvantaged: The inner city, the underclass, and public policy. University of Chicago Press. 
Table 1: Descriptive Statistics

\begin{tabular}{|c|c|c|}
\hline Variable & Mean & Std.Dev. \\
\hline \multicolumn{3}{|l|}{ Dependent Variables } \\
\hline Violent Crime 2007-2009 & 140.61 & 91.07 \\
\hline Property Crime 2007-2009 & 717.49 & 404.95 \\
\hline Homicides 2007-2009 & 1.53 & 1.85 \\
\hline Rape 2007-2009 & 6.66 & 5.72 \\
\hline Robbery 2007-2009 & 57.20 & 40.35 \\
\hline Aggravated Assault 2007-2009 & 75.22 & 51.30 \\
\hline Burglary 2007-2009 & 207.58 & 106.68 \\
\hline Larceny 2007-2009 & 418.26 & 303.32 \\
\hline Vehicle Theft 2007-2009 & 91.65 & 55.47 \\
\hline \multicolumn{3}{|l|}{ Income Variables } \\
\hline Tract Mean Household Income & $\$ 55,874.38$ & $\$ 27,811.87$ \\
\hline Tract Gini Coefficient & 0.40 & 0.06 \\
\hline Ratio adjacent tract to tract income & 1.13 & 0.33 \\
\hline \multicolumn{3}{|l|}{ Control Variables } \\
\hline Percent African-American & 30.69 & 29.12 \\
\hline Percent Hispanic & 6.36 & 7.43 \\
\hline Percent Population Males aged 15 to 24 & 13.99 & 7.79 \\
\hline Disadvantage Index (female headed households and unemployed) & $(0.00)$ & 1.24 \\
\hline Stability Index (Same Residence for Past 5 years and owner-occupied) & $(0.00)$ & 1.29 \\
\hline Adapted Herfindahl Index & 0.37 & 0.18 \\
\hline
\end{tabular}


Table 2. Violent Crime

\begin{tabular}{|c|c|c|c|c|c|}
\hline Independent variables & $\begin{array}{l}\text { Violent } \\
\text { crimes }\end{array}$ & Homicides & Rapes & Robberies & $\begin{array}{l}\text { Aggravated } \\
\text { assaults }\end{array}$ \\
\hline Mean income (thousands) & $\begin{array}{l}-0.0206^{\star \star \star} \\
(0.00232)\end{array}$ & $\begin{array}{l}-0.0114^{*} \\
(0.00577)\end{array}$ & $\begin{array}{l}-0.0278^{\star \star \star} \\
(0.00417) \\
\end{array}$ & $\begin{array}{l}-0.0172^{\star \star \star} \\
(0.00287)\end{array}$ & $\begin{array}{l}-0.0228^{\star \star \star} \\
(0.00250)\end{array}$ \\
\hline $\begin{array}{l}\text { Tract income Gini } \\
\text { coefficient }\end{array}$ & $\begin{array}{l}3.088^{\star * \star} \\
(0.601)\end{array}$ & $\begin{array}{c}2.558 \\
(1.338) \\
\end{array}$ & $\begin{array}{l}3.726^{\star \star \star} \\
(0.881)\end{array}$ & $\begin{array}{l}4.372^{\star \star \star} \\
(0.774)\end{array}$ & $\begin{array}{l}1.942^{\star \star} \\
(0.594)\end{array}$ \\
\hline $\begin{array}{l}\text { Ratio adjacent to tract } \\
\text { mean income }\end{array}$ & $\begin{array}{l}-0.478^{\star * \star} \\
(0.131)\end{array}$ & $\begin{array}{l}-0.560 \\
(0.288)\end{array}$ & $\begin{array}{l}-0.585^{\star \star} \\
(0.200)\end{array}$ & $\begin{array}{l}-0.275 \\
(0.155)\end{array}$ & $\begin{array}{l}-0.596 * \star \star \\
(0.137)\end{array}$ \\
\hline $\begin{array}{l}\text { Herfindahl race-ethnicity } \\
\text { heterogeneity index }\end{array}$ & $\begin{array}{l}-0.354 \\
(0.225)\end{array}$ & $\begin{array}{l}-0.369 \\
(0.490)\end{array}$ & $\begin{array}{l}-0.173 \\
(0.345)\end{array}$ & $\begin{array}{l}-0.279 \\
(0.297) \\
\end{array}$ & $\begin{array}{l}-0.375 \\
(0.219) \\
\end{array}$ \\
\hline Percent African-American & $\begin{array}{l}0.00395^{\star} \\
(0.00164)\end{array}$ & $\begin{array}{l}0.0146^{\star \star \star} \\
(0.00414)\end{array}$ & $\begin{array}{c}0.00125 \\
(0.00227)\end{array}$ & $\begin{array}{c}0.00391 \\
(0.00216)\end{array}$ & $\begin{array}{l}0.00386^{*} \\
(0.00157)\end{array}$ \\
\hline Percent Hispanic & $\begin{array}{c}0.00394 \\
(0.00554)\end{array}$ & $\begin{array}{c}0.0178 \\
(0.0127)\end{array}$ & $\begin{array}{l}-0.00364 \\
(0.00814)\end{array}$ & $\begin{array}{c}0.00505 \\
(0.00704)\end{array}$ & $\begin{array}{c}0.00245 \\
(0.00539)\end{array}$ \\
\hline Percent males aged 15-24 & $\begin{array}{l}-0.0146^{\star *} \\
(0.00465)\end{array}$ & $\begin{array}{l}-0.0222 \\
(0.0130)\end{array}$ & $\begin{array}{l}-0.00740 \\
(0.00661)\end{array}$ & $\begin{array}{l}-0.0183^{\star *} \\
(0.00637)\end{array}$ & $\begin{array}{l}-0.0110^{\star} \\
(0.00441)\end{array}$ \\
\hline $\begin{array}{l}\text { Disadvantage index } \\
\text { (female-headed \& } \\
\text { unemployed) }\end{array}$ & $\begin{array}{l}-0.0248 \\
(0.0467)\end{array}$ & $\begin{array}{l}0.161 \\
(0.101)\end{array}$ & $\begin{array}{l}-0.0571 \\
(0.0686)\end{array}$ & $\begin{array}{l}-0.0659 \\
(0.0617)\end{array}$ & $\begin{array}{l}0.00461 \\
(0.0454)\end{array}$ \\
\hline $\begin{array}{l}\text { Stability index (same } \\
\text { residence \& owner- } \\
\text { occupied) }\end{array}$ & $\begin{array}{l}-0.176^{\star \star \star} \\
(0.0343) \\
\end{array}$ & $\begin{array}{l}-0.0809 \\
(0.0862) \\
\end{array}$ & $\begin{array}{l}-0.169 * \star \star \\
(0.0499)\end{array}$ & $\begin{array}{l}-0.164^{\star \star \star} \\
(0.0453)\end{array}$ & $\begin{array}{l}-0.171^{* \star *} \\
(0.0332)\end{array}$ \\
\hline Spatial lag of crimes & $\begin{array}{l}0.00314^{\star \star \star} \\
(0.000706)\end{array}$ & $\begin{array}{c}0.144 \\
(0.0878)\end{array}$ & $\begin{array}{c}0.0147 \\
(0.0181)\end{array}$ & $\begin{array}{l}0.0113^{\star \star \star} \\
(0.00208)\end{array}$ & $\begin{array}{c}0.00642^{\star \star \star} \\
(0.00123)\end{array}$ \\
\hline Constant & $\begin{array}{c}-3.166^{\star \star *} \\
(0.355) \\
\end{array}$ & $\begin{array}{c}-8.152^{\star \star \star} \\
(0.769)\end{array}$ & $\begin{array}{c}-5.665^{\star \star \star} \\
(0.535)\end{array}$ & $\begin{array}{c}-5.161^{\star \star \star} \\
(0.420)\end{array}$ & $\begin{array}{c}-3.203^{\star \star \star} \\
(0.369)\end{array}$ \\
\hline Observations & 188 & 188 & 188 & 188 & 188 \\
\hline Log likelihood & -993.6 & -274 & -489.6 & -867.3 & -867.2 \\
\hline $\mathrm{Chi}^{2}$ & $273.9^{\star \star \star}$ & $124.1^{\star \star \star}$ & $156.9^{\star \star \star}$ & $193.8^{\star \star \star}$ & $302.1^{\star \star \star}$ \\
\hline
\end{tabular}

Standard errors in parentheses, ${ }^{* \star *} p<0.001,{ }^{* \star} p<0.01,{ }^{*} p<0.05$ 


\begin{tabular}{|c|c|c|c|c|}
\hline Independent variables & $\begin{array}{l}\text { Property } \\
\text { crimes }\end{array}$ & Burglaries & Larcenies & $\begin{array}{l}\text { Vehicle } \\
\text { thefts }\end{array}$ \\
\hline \multirow[t]{2}{*}{ Mean income (thousands) } & $-0.0135^{\star \star \star}$ & $-0.0130 * \star *$ & $-0.0108^{\star \star \star}$ & $-0.0200 * \star \star *$ \\
\hline & $(0.00187)$ & $(0.00166)$ & $(0.00220)$ & $(0.00234)$ \\
\hline \multirow[t]{2}{*}{ Tract income Gini coefficient } & $1.572^{\star \star}$ & $1.263^{\star \star}$ & $1.482^{\star}$ & $1.694^{\star \star}$ \\
\hline & $(0.589)$ & $(0.479)$ & $(0.708)$ & $(0.590)$ \\
\hline \multirow[t]{2}{*}{$\begin{array}{l}\text { Ratio adjacent to tract mean } \\
\text { income }\end{array}$} & $-0.400^{\star \star \star *}$ & $-0.281^{\star \star}$ & $-0.348^{\star *}$ & $-0.467^{\star \star \star}$ \\
\hline & $(0.113)$ & $(0.0985)$ & $(0.132)$ & $(0.125)$ \\
\hline \multirow{2}{*}{$\begin{array}{l}\text { Herfindahl race-ethnicity } \\
\text { heterogeneity index }\end{array}$} & -0.137 & 0.215 & -0.295 & -0.0825 \\
\hline & $(0.219)$ & $(0.183)$ & $(0.266)$ & $(0.217)$ \\
\hline \multirow[t]{2}{*}{ Percent African-American } & 0.000153 & $0.00272^{*}$ & -0.00212 & 0.00299 \\
\hline & $(0.00164)$ & $(0.00133)$ & $(0.00201)$ & $(0.00159)$ \\
\hline \multirow[t]{2}{*}{ Percent Hispanic } & 0.000665 & 0.00228 & 0.00167 & -0.00152 \\
\hline & $(0.00535)$ & $(0.00446)$ & $(0.00647)$ & $(0.00531)$ \\
\hline \multirow[t]{2}{*}{ Percent males aged 15-24 } & -0.00880 & $-0.0154^{\star \star \star}$ & -0.00571 & $-0.0103^{\star}$ \\
\hline & $(0.00484)$ & $(0.00403)$ & $(0.00592)$ & $(0.0048)$ \\
\hline \multirow{2}{*}{$\begin{array}{l}\text { Disadvantage index (female- } \\
\text { headed \& unemployed) }\end{array}$} & -0.0614 & 0.0300 & -0.0843 & -0.0484 \\
\hline & $(0.0448)$ & $(0.0382)$ & $(0.0543)$ & $(0.0450)$ \\
\hline \multirow[t]{2}{*}{$\begin{array}{l}\text { Stability index (same } \\
\text { residence \& owner-occupied) }\end{array}$} & $-0.172^{\star \star \star}$ & -0.0293 & $-0.232^{\star \star \star}$ & $-0.149^{* \star \star}$ \\
\hline & $(0.0327)$ & $(0.0301)$ & $(0.0388)$ & $(0.0338)$ \\
\hline \multirow[t]{2}{*}{ Spatial lag of crimes } & 0.000163 & $0.00153^{\star \star}$ & 0.000218 & $0.00570^{* \star *}$ \\
\hline & $(0.000154)$ & $(0.000491)$ & $(0.000258)$ & $(0.00109)$ \\
\hline \multirow[t]{2}{*}{ Constant } & $-1.012^{\star \star}$ & -2.659 *** & $-1.625^{\star \star *}$ & $-3.255^{\star \star \star}$ \\
\hline & $(0.332)$ & $(0.290)$ & $(0.371)$ & $(0.362)$ \\
\hline Observations & 188 & 188 & 188 & 188 \\
\hline Log likelihood & $-1,312$ & $-1,043$ & $-1,238$ & -913.4 \\
\hline $\mathrm{Chi}^{2}$ & $134.7^{\star \star \star}$ & $190.1^{\star \star \star}$ & $106.6^{\star \star \star}$ & $242.2^{\star \star \star}$ \\
\hline
\end{tabular}


Table 4: Marginal Effect* based on Standard Deviation Change in Inequality Variables**

\begin{tabular}{|c|c|c|c|}
\hline Dependent Variables & Mean Income & $\begin{array}{l}\text { Tract income } \\
\text { Gini coefficient }\end{array}$ & Ratio Adjacent to Tract \\
\hline & \multicolumn{3}{|c|}{ Violent Crime } \\
\hline Homicides $(\mu=1.5)$ & -0.13 & 0.20 & -0.09 \\
\hline Rapes $(\mu=6.7)$ & -3.03 & 1.60 & -0.80 \\
\hline Robberies $(\mu=57.2)$ & -22.34 & 18.20 & -5.83 \\
\hline \multirow[t]{2}{*}{ Aggravated Assaults $(\mu=75.2)$} & -33.94 & 9.54 & -13.71 \\
\hline & \multicolumn{3}{|c|}{ Property Crime } \\
\hline Burglaries $(\mu=207.6)$ & -63.10 & 13.85 & -14.09 \\
\hline Larcenies $(\mu=418.3)$ & -104.58 & 41.71 & -37.73 \\
\hline Vehicle Thefts $(\mu=91.7)$ & -42.35 & 10.42 & -13.80 \\
\hline
\end{tabular}




\section{Appendix}

Our preferred models include mean household income, the Gini coefficient, and the ratio of adjacent tract income to immediate tract income. However, given the mixed results of previous studies, we acknowledge and are sensitive to the possibility that the misspecification of income inequality measures may affect our conclusions. We examined multiple models using different measures of income level and within and between tract inequality to determine the extent to which our preferred operationalization of income inequality affects outcomes, and ultimately our conclusions. Each income measure was replaced in the base model one at a time, while all other variables in the models remained the same (see Table 2 for base model). For instance, in one model, mean tract income was replaced with mean log income in the base model. In another model, median tract income was included as the measure for income level. A total of 10 models with replacements were considered. Table 1a summarizes the results for each of the models and the relationship between each measure and total violent and property crime counts. Results for all other variables are suppressed and available upon request. Specifically, Table 1a shows the sign (i.e., directionality) and significance of the variables of interest.

\section{TABLE 1a here}

As shown, the fit of each model is generally consistent. There is little variation in the model log likelihoods and $\mathrm{Chi}^{2}$ statistics. The sign of each coefficient is consistent across all models. All measures of tract income level and adjacent tract variation are negatively related to violent and property crimes. With the exception of the coefficient of variation of log income, within tract inequality measures are consistently positively related to violent and property crimes at $p<0.01$. 
Table 1a: Comparison of Directionality and Significance of Repeated Measure Substitution in Preferred Model

\begin{tabular}{|c|c|c|c|}
\hline & Relationship & Log likelihood & $\mathrm{Chi}^{2}$ \\
\hline & \multicolumn{3}{|c|}{ Violent Crimes } \\
\hline \multicolumn{4}{|l|}{ Income Levels } \\
\hline Mean income (preferred measure) & $-* * *$ & -994 & $273.9 * * *$ \\
\hline Mean log income & $-* * *$ & $-1,000$ & $261.8 * * *$ \\
\hline Median income & $-* * *$ & -999 & $263.5^{* * *}$ \\
\hline \multicolumn{4}{|l|}{ Within Tract Income Inequality } \\
\hline Tract income Gini Coefficient (preferred measure) & $+* * *$ & -994 & $273.9 * * *$ \\
\hline Coefficient of variation of log income & $+* * *$ & $-1,000$ & $261.5 * * *$ \\
\hline Coefficient of variation of income & $+* * *$ & -990 & $280.2 * * *$ \\
\hline Interquartile range divided be median income & $+* * *$ & -996 & $269.9 * * *$ \\
\hline \multicolumn{4}{|l|}{ Between-tract Inequality } \\
\hline Ratio adjacent to tract mean income (preferred measure) & $-* * *$ & -994 & $273.9 * * *$ \\
\hline Ratio adjacent to tract mean log income & $-* * *$ & -994 & $273.7 * * *$ \\
\hline \multirow[t]{2}{*}{ Ratio adjacent to tract median income } & $-* * *$ & -991 & $277.6 * * *$ \\
\hline & \multicolumn{3}{|c|}{ Property Crimes } \\
\hline \multicolumn{4}{|l|}{ Income Levels } \\
\hline Mean income (preferred measure) & $-* * *$ & $-1,312$ & $134.7 * * *$ \\
\hline Mean log income & $-* * *$ & $-1,313$ & $131.8 * * *$ \\
\hline Median income & $-* * *$ & $-1,311$ & $136.5 * * *$ \\
\hline \multicolumn{4}{|l|}{ Within Tract Inequality } \\
\hline Tract income Gini Coefficient (preferred measure) & $+* *$ & $-1,312$ & $134.7 * * *$ \\
\hline Coefficient of variation of log income & + & $-1,315$ & $128.8^{* * *}$ \\
\hline Coefficient of variation of income & $+* * *$ & $-1,309$ & $139.3^{* * *}$ \\
\hline Interquartile range divided be median income & $+* *$ & $-1,312$ & $135.1 * * *$ \\
\hline \multicolumn{4}{|l|}{ Adjacent Tract Inequality } \\
\hline Ratio adjacent to tract mean income (preferred measure) & $-* * *$ & $-1,312$ & $134.7 * * *$ \\
\hline Ratio adjacent to tract mean log income & $-* * *$ & $-1,311$ & $135.9 * * *$ \\
\hline Ratio adjacent to tract median income & $-* * *$ & $-1,309$ & $139.3 * * *$ \\
\hline
\end{tabular}
(-) indicates negative relationship
$(+)$ indicate positive relationship
$* * * \mathrm{p}<0.001, * * \mathrm{p}<0.01, * \mathrm{p}<0.05$ 